\title{
Frankokratia: A Journal for the Study of Greek Lands under Latin Rule
}

A Message from the Editors

Given the spectacular rise in the number of research periodicals across all academic disciplines in recent decades, the launching of a new journal requires an explanation. We consider the creation of Frankokratia a long-overdue service to a growing international field, the somewhat unfocused development of which has often been torn between the exigencies of national history and the broad-brush treatment of Eurocentric or global narratives. To be sure, Frankokratia is not meant to essentialize the field by replacing local Greek and Cypriot journals or discouraging publication in periodicals engaging more broadly with the history, art history, and archaeology of the Middle Ages and early modernity. It has been conceived as nothing more (or less) than a specialized interdisciplinary forum of the highest quality, submissions to which will be subjected to the double-blind peer-review process common to highranking publications in the humanities. Papers will be accepted on the merits of originality of thought and incisiveness of argumentation with the aim of benefitting a learned readership, including not only the professional historian, but also the graduate student and the educated enthusiast. With this goal in mind, and starting out with a relatively small number of pages, we anticipate an elevated rejection rate, meaning that sometimes even competently crafted papers may, for one reason or another, not be accommodated in Frankokratia. Although we are committed to being as objective and inclusive as possible, we kindly ask, in advance, of the prospective authors of papers for which the journal's reviewers will not recommend publication to take any comments as constructive criticism for possible future publication elsewhere.

The contents of the inaugural volume represent well our original vision for Frankokratia in terms of both scope and diversity. Our flagship paper, tackling the term "Frankokratia" itself, is the first of a series of commissioned articles on critical issues pertinent to the study of Latin rule in Greece and Cyprus. Of the dozens of specialists called upon by Brill to evaluate our proposal for the present journal's creation, the overwhelming majority thought that, as a concept, Frankokratia was a worthwhile venture; notable disagreement arose only with respect to our choice of the Greek word for "Frankish rule" as the publication's 
title. Even members of our editorial board (some of whom were undoubtedly among Brill's experts) expressed reservations, because the term "Frankokratia" may be interpreted in a pejorative and/or biased light. Nevertheless, we felt that, since the term remains so absolutely pervasive in Greek-language scholarly writing, it needed to be confronted and understood, rather than vilified and avoided. Gilles Grivaud and Angel Nicolaou-Konnari have taken up the task of exploring in depth the term's origins and subsequent fate within the modern and contemporary intellectual milieux in an erudite, book-length piece that will be published in two instalments. It is our hope that, once the term's raison-dêtre and ideological connotations are fully unpacked and realized, "Frankokratia" will be able to serve as a convenient neutral(ized) shorthand for a field currently devoid of an agreed-upon name on the international stage, much like other once-derogatory terms, such as "medieval," "Byzantine," "Gothic," and so on.

Because of its Greek pedigree, the term "Frankokratia" applies above all to areas of modern Hellenism under Western rule in the High and Late Middle Ages, yet the journal is intended to have a broader remit than the study of Greece and Cyprus after the Third and Fourth Crusades. We have commissioned some and hope to receive more submissions on analogous phenomena elsewhere, such as Transylvania, where elites religiously loyal to Rome ruled over people religiously loyal to Constantinople. We also encourage papers that focus on connections between the areas of Hellenism ruled directly by Latins and other territories. Our second paper, by Filip Van Tricht, examines thirteenth-century marriage alliances between Latins in the Empire of Constantinople and Serbians, a political and prosopographical reevaluation accompanied by six genealogical tables. In our third paper, Michele Bacci switches gears to art history and, in yet another contribution concerned with origins, attempts to trace the beginnings of the fifteenth-century "Cretan School" of icon painting in the artistic traditions of the fourteenth-century Mediterranean. Frankokratia will also publish book reviews, occasionally lengthy review essays, and commissioned surveys of the field. In this volume, we include our own review essay of the recent book on the archaeology of Cistercian Zaraka Abbey in the Peloponnese, updating what we know about the abbey in the context of the Cistercians in Romania.

Dealing in history, art history, archaeology, the Latin Empire of Constantinople, the Frankish Morea, Venetian Crete, and multiple connections or comparisons with outside territories, this first volume of Frankokratia illustrates well the journal's varied focus and desired level of quality.

Michalis Olympios and Christopher Schabel

University of Cyprus, Nicosia 